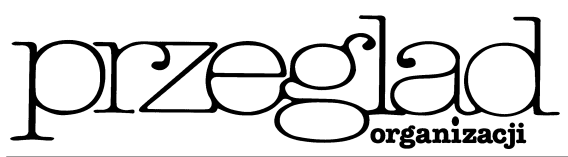

\title{
Facility Management jako strukturalne wsparcie koncepcji outsourcingu i Lean Enterprise
}

https://doi.org/10.33141/po.2005.78.04

Sławomir Kądziela

\section{Wprowadzenie}

$\mathbf{N}$ iniejsze opracowanie ma na celu wskazanie korzyści z zastosowania koncepcji Facility $M a-$ nagement (czyli zarządzania działalnością pomocniczą), będącej w Polsce stosunkowo nowym zagadnieniem, w niewielkim stopniu opracowanym w literaturze z zakresu organizacji i zarządzania. Facility $M a-$ nagement zostanie przedstawiony jako koncepcja wspierająca elastyczność organizacji przemysłowych i usługowych, wykorzystująca zalety outsourcingu i Lean Enterprise / Lean Management.

\section{Lean Management / Lean Enterprise}

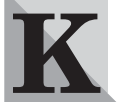

oncepcja Lean Management (Lean Enterprise), czyli zarządzania wysmukłego (zarządzania odchudzonego / przedsiębiorstwa wysmukłego) wywodzi się z obserwacji japońskiej praktyki zarządzania produkcją w przemyśle samochodowym, które to obserwacje zaowocowały powstaniem w USA spójnej teorii racjonalizatorskiej [11, s. 101 i dalsze]. W praktyce japonskiej pracownik jest nieustannie szkolony i przygotowywany do pracy w kilkuosobowych zespołach, wykonujących kompleksowo zamknięte fragmenty procesu produkcyjnego [11, s. 101]; w połączeniu z ciaggłą rotacją pracowników między zespołami oraz z redukcjami liczby pracowników, system taki zaowocował znaczącym wzrostem wydajności pracy i oszczędności w zakresie zatrudnienia (stąd nazwy: „wysmukła” lub „odchudzona” organizacja).

Podstawą omawianej koncepcji jest „koncentracja działalności firmy na procesie tworzenia wartości, a nie na podziale zadań i specjalizacji stanowisk. Koncepcja odchudzonego przedsiębiorstwa zmierza do wykorzystania (...) efektów synergicznych (...)" [3, s. 251], poprzez elastyczne zagospodarowanie kompetencji pracowników w zespołach i jednostkach produkcyjnych.

Do głównych zasad stosowanych przy „odchudzaniu” przedsiębiorstwa należą [11, s. 103]:

- prospektywiczność (przewidywanie i kształtowanie przyszłych działań),

- wrażliwość (zrozumienie otoczenia oraz reagowanie w celu adaptacji),

- globalność (rozważenie efektów całościowych w ich złożoności),

- dynamiczność (wykorzystanie wszystkich zasobów posiadanych przez organizację),

- oszczędność (eliminacja marnotrawstwa).
Przegląd Organizacji, Nr 7/8 (786/787), 2005, ss. 18-20

www.przegladorganizacji.pl Towarzystwo Naukowe Organizacji i Kierownictwa (TNOiK)
Celem Lean Managementu jest uproszczenie organizacji, przejawiające się w spłaszczeniu struktur [15, s. 61], eliminacji części kosztów działalności pomocniczej (np. redukcja zapasów i powierzchni magazynowej) [13] oraz powiązaniu odpowiedzialności jednostki z celami organizacji. A. Czermiński wskazuje, że „filozofii odchudzonego przedsiębiorstwa towarzyszy proces przekazywania części działalności (...) na zewnątrz do wyspecjalizowanych firm. W przypadku przedsiębiorstw produkcyjnych obserwuje się proces ograniczenia liczby operacji i produkcji podzespołów wykonywanych we własnym zakresie i przekazywanie ich na zewnątrz (outsourcing)" [3, s. 252, 253].

\section{Outsourcing}

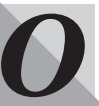

utsourcing jest określany jako „przedsięwzięcie, polegajacce na wydzieleniu ze struktury organizacyjnej przedsiębiorstwa macierzystego realizowanych przez nie funkcji” [14, s. 53-54]. Klasyczne ujęcie outsourcingu wywodzi się ze zlecania części funkcji zakładów produkcyjnych na zewnatrz. Praktyka współczesnej gospodarki skłania się w dużej mierze w kierunku outsourcingu usług. W. Zimniewicz zauważa, że „koncepcja outsourcingu zakłada również tworzenie nowego modelu w zakresie usług. (...) Można zrezygnować z usług, które nie maja istotnego znaczenia dla firmy i mogą być świadczone przez specjalistyczne przedsiębiorstwa" [15, s. 53]. Badacz, powołując się na niemieckie doświadczenia w zakresieoutsourcingu, prezentuje typologię usług najczęściej wydzielanych poza przedsiębiorstwa, w układzie kryteriów stopnia integracji oraz stopnia złożoności usług [15, s. 54]:

- usługi złożone, o wysokim stopniu integracji z działalnością podstawową: przetwarzanie informacji, zaopatrzenie,

- usługi złożone, o niskim stopniu integracji: utrzymanie ruchu, obsługa techniczna,

- usługi proste, o wysokim stopniu integracji: księgowość, kadry, finanse,

- usługi proste, o niskim stopniu integracji: ochrona, czystość, catering.

Przedstawiona poniżej szczegółowo koncepcja Facility Management jest pochodną teoriioutsourcingu w zakresie usług o niskim stopniu integracji (usług pomocniczych) oraz wkomponowuje się w teorie „zarządzania/ przedsiębiorstwa odchudzonego". Z tego też powodu, jak również z uwagi na dotychczas niewielki zakres obecno- 
ści tej koncepcji w polskiej literaturze oraz praktyce zarządzania, opis Facility Management zasługuje na szersze ujęcie.

\section{Facility Management}

$\mathbf{P}$ raktycznym sposobem wdrożenia strategii elastyczności w organizacjach jest koncepcja $F a$ cility Management. Pochodzenie Facility Management datuje się na przełom lat 70. i 80. ub. wieku, kiedy w Stanach Zjednoczonych wykształciła się dziedzina nadzorowania funkcji eksploatacyjnych oraz administracyjnych budynków [12, s. 16]. Na początku lat 90. w Wielkiej Brytanii powstał British Institute of Facilities Management i od tego czasu datuje się rozwój koncepcji w praktyce zarządzania obiektami komercyjnymi, publicznymi oraz przemysłowymi w Europie Zachodniej.

Istota Facility Management jest redukcja kosztów działalności podstawowej. W praktyce branżowej spotkać można podejście, że wobec wysokiej konkurencyjności gospodarki oraz silnej presji na redukcję kosztów, reorganizacja procesów biznesowych przedsiębiorstw jest wspomagana outsourcingiem usług Facility Management, jako stylem zarządzania [2, s. IX].

Według terminologii kontynentalnej używa się sformułowania Facility Management, zaś teoretycy i praktycy z Wielkiej Brytanii i Stanów Zjednoczonych formułują nazwę dziedziny jako Facilities Management. Oba określenia sa zbieżne i oba są nieprzetłumaczalne na język polski. Angielskie słowo facility (w liczbie mnogiej facilities) jest rozumiane jako „ułatwienie”, „udogodnienie" lub „urzadzenie”.

Pierwotny zakres koncepcji, ograniczajacy się do zarządzania nieruchomościami w ujęciu technicznym i administracyjnym, w celu redukcji kosztów bieżącej obsługi [8], jest ujęciem wąskim i niezbyt adekwatnym do praktyki we współczesnej gospodarce. Branżowe organizacje międzynarodowe definiuja dziedzine Facility Management jako: „,interdyscyplinarną profesję, której celem jest zapewnienie funkcjonalności zabudowanego środowiska poprzez integrację ludzi, miejsca, procesów i technologii” [6] oraz: „integrację multidyscyplinarnych aktywności w obszarze zabudowanego środowiska oraz zarządzanie wpływem tych aktywności na człowieka i jego miejsce pracy" [1].

Szeroka definicja Facility Management oznacza kompleksowe zarządzanie działalnością pomocniczą organizacji, usługi nadzoru nad infrastruktura oraz techniką i technologiami nieruchomości oraz „ruchomościowymi” elementami organizacji, „usługi zarządzania wszystkimi niekluczowymi dla firmy obszarami jej działalności” [12, s. 16]. Istnieja tendencje do wyznaczania standardów praktyki zawodów związanych z Facility Management [7], a nawet prowadzone sa unijne projekty standaryzacji [12, s. 14, 15], jednak jedynym wspólnym mianownikiem dla branży oraz koncepcji Facility Management wydaje się być wspomniane „kompleksowe i zintegrowane zarządzanie działalnością pomocnicza”.

Według kryterium zakresu zarzązania, usługi działalności Facility Management można podzielić na zarządzanie strategiczne (planowanie, projektowanie, doradztwo) oraz operacyjne (organizowanie, wykonawstwo, egzekwowanie, kontrola).

Usługi Facility Management dzieli się na trzy podstawowe grupy:
- ekonomiczny Facility Management: administrowanie umowami, zarządzanie powierzchniami użytkowymi, księgowość obiektów wraz z budżetowaniem, planowanie i kontrola kosztów działalności pomocniczej,

- infrastrukturalny Facility Management: ochrona obiektów, kontrola ruchu osób i przepływu materiałów, obsługa recepcji, zarządzanie powierzchniami parkingowymi,

- techniczny Facility Management: obsługa budynków w zakresie konserwacyjnym (utrzymanie substancji budowlanej), obsługa techniczna urzadzeń i sieci mediów (obsługa operatorska, utrzymanie ruchu - przeglądy, konserwacje, prowadzenie dokumentacji, usuwanie awarii), obsługa techniczna linii produkcyjnych (usługi operatorskie, konserwacje, serwis).

Facility Management pozwala organizacjom na koncentrację na działalności podstawowej. Umożliwia odchudzenie strukturalne i przedmiotowe działalności oraz koncentrację zasobów ludzkich i materialnych na kluczowych kompetencjach. W zakresie globalnym usługi zarzadzania działalnościa pomocnicza sa standaryzowane oraz asymiluja nowoczesne trendy organizacyjne i technologie służące do efektywnego zarządzania nieruchomościami, techniką i infrastrukturą organizacji. Redukcja zatrudnienia i oszczędności w zakresie kosztów obsługi działalności pomocniczej to ostatnie z wymienionych, lecz nie najmniej ważne, cechy współpracy z przedsiębiorstwami Facility Management.

W przemyśle oraz usługach publicznych w gospodarkach rozwiniętych, koncepcje outsourcingu oraz Facility Management sa szeroko zakorzenione i wykorzystywane praktycznie [9]. Opisane poniżej korzyści wynikajace ze stosowania Facility Management stanowią powszechnie akceptowany argument do prowadzenia tego typu działań usprawniających funkcjonowanie organizacji. Rosnaca siłę branży Facility Management potwierdzają np. dane o dynamice obrotów niemieckich przedsiębiorstw sektora [10, s. 18 i dalsze] - rok 2002/2001 $3,5 \%, 2003 / 2002-5 \%$, zaś zgodnie z prognozą: $2004 / 2003$ - $11,7 \%$; w odniesieniu do danych o przyroście zatrudnienia w tych firmach (dla odpowiednich okresów: 0\%, $1 \%, 6 \%$ ).

Wśród podstawowych argumentów przemawiających za wdrożeniem koncepcji Facility Management przeważają korzyści tożsame z tymi, które charakteryzują dziedzinę outsorcingu, np. redukcja kosztów działalności obsługiwanej przez podmiot zewnętrzny oraz realokacja zatrudnienia, połączona z restrukturyzacją działów organizacji (zmniejszenie i spłaszczenie struktury organizacyjnej), zwiększenie wydajności pracy (skrócenie drogi decyzyjnej, poprawa komunikacji) oraz przejrzystość kalkulacji kosztów i pomiaru efektywności.

Do korzyści specyficznych dla usług Facility Management należy zaliczyć:

- poprawę jakości obsługi (dzięki wyspecjalizowaniu oraz koncentracji na jakości jednostek zewnętrznych),

- wzrost identyfikacji i motywacji pracowników (przejrzystość celów organizacji i możliwość systemów wynagradzania za efekty),

- elastyczność i przerzucenie ryzyka zarządzania personelem na podmioty zewnętrzne,

- możliwość wykorzystania specyficznych zasobów (technologie, wiedza),

- egzekwowalność jakości i niezawodności usług,

- zarządzanie kompleksowe i zintegrowane (efekt synergii zarzadzania, uproszczenie procedur i zogniskowanie odpowiedzialności), 
- zarządzanie globalne (standardy i technologie wykorzystywane $\mathrm{w}$ przedsiębiorstwach międzynarodowych oraz ich adaptacja do warunków lokalnych).

Z uwagi na wymóg elastyczności oraz profesjonalizacji działalności Facility Management, gros usługodawców to ponadregionalne organizacje, skupiające w strukturach holdingowych lokalne terytorialnie (a nawet: dedykowane pojedynczemu obiektowi) jednostki podstawowe. Minimalizacji szczebli nadzoru w ramach jednostek podstawowych towarzyszy nadzór funkcjonalny (techniczny i technologiczny) lub struktury doradcze, zlokalizowane w jednostkach nadrzędnych. Ponieważ główny zakres usług dotyczy funkcji słabo zintegrowanych z działalnością podstawową usługobiorcy, obsługa sfery pomocniczej prowadzona przez jednostki zewnętrzne, ale blisko związane z usługodawcą (komunikacja, raportowanie, partnerstwo), wydaje się najbardziej efektywna.

Powszechną tendencjąjest koncentracja na własnych pracownikach w ramach jednostek usługodawców oraz elastyczne alianse $\mathrm{z}$ wysoce wyspecjalizowanymi przedsiębiorstwami zewnętrznymi. Szczególnie w przypadku usług technicznie i organizacyjnie złożonych, o efektach skali i synergii zarządzania decyduje umiejętność gromadzenia własnych kompetencji w ramach wielości dyscyplin (funkcji) wchodzących w skład Facility Management.

Granice między usługodawcą i usługobiorcą są płynne w zakresie świadczenia działalności i jej koordynacji; każdy konkretny kontrakt zawiera zakres obowiązków, jednak z uwagi na fakt, że działalność Facility Management jest prowadzona na rzecz i na terenie organizacji usługobiorcy, partnerskie dostosowywanie się do bieżących potrzeb, tak w dziedzinie nadzoru i koordynacji, jak i zakresu usług szczegółowych, podlegać może ciągłym negocjacjom i zmianom.

Jednostki podstawowe przedsiębiorstw Facility $M a$ nagement również graniczą ze sobą w sposób elastyczny. Wzajemne wykorzystywanie kompetencji, zasobów materialnych i personelu, doradztwo, realokacja pracowników, szkolenia itp. wymagają otwartego podejścia do kwestii granic organizacyjnych. Wzorem elastycznej struktury, skupiającej podmioty o wyspecjalizowanych kompetencjach, może być sieć tworzona w ramach międzynarodowych organizacji zrzeszajacych podmioty branżowe [4] oraz grupy interesów, tworzące alianse na rynku globalnym [5].

Organizacje, prowadzące działalność skoncentrowaną na core business i core competence (działalność

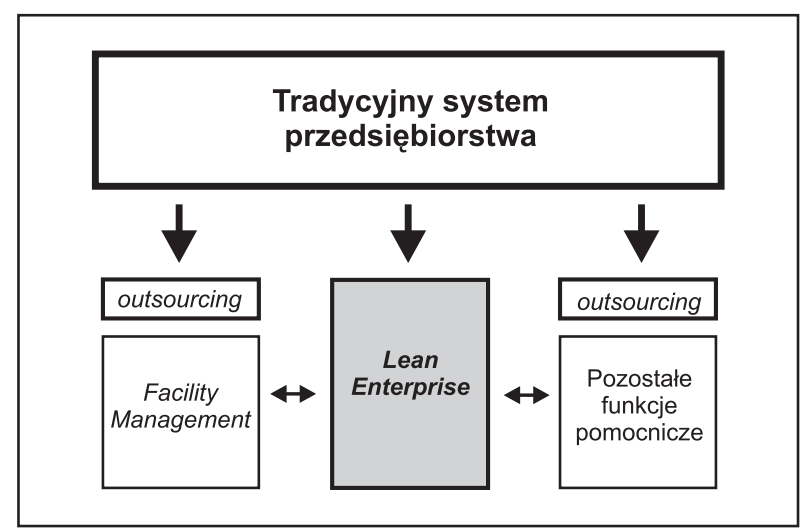

Rys. Model przejścia od przedsiębiorstwa tradycyjnego do organizacji odchudzonej

Źródło: opracowanie własne. i kompetencje podstawowe) wyprowadzają na zewnątrz funkcje pomocnicze. Jednocześnie, zgodnie $\mathrm{z}$ teorią „przedsiębiorstwa odchudzonego”, jednostki organizacyjne, które pozostają w firmie macierzystej, zarządzane są w sposób kompleksowy (integracja funkcji w ramach pojedynczego produktu końcowego) oraz elastyczny (rotacje pracowników między jednostkami).

„Przedsiębiorstwo odchudzone” zleca funkcje pomocnicze na zewnątrz, koordynując wykonanie tych funkcji $\mathrm{w}$ formie outsourcingu. W przypadku łączenia zarządzania rozproszonymi i nie pokrewnymi ze sobą funkcjami w ramach jednego podmiotu multidyscyplinarnego, można ów model nazwać zarządzaniem działalnością pomocniczą w formie outsourcingu sfery Facility Management.

Oprócz kontraktu, partnerstwa i rzeczywistego świadczenia usług, „organizacja wysmukła” i usługodawca Facility Management mają kolejny wspólny obszar: zarządzanie kompleksowe. Zarówno w ramach organizacji macierzystej, jak i jednostki zewnętrznej, zasadą efektywności jest kompleksowość i synergia w zakresie prowadzonej działalności.

Powyższy model wskazuje na zasadę wykorzystania outsourcingu jako sposobu „wyszczuplenia” organizacji tradycyjnej. W przedsiębiorstwie pozostają jedynie funkcje podstawowe (core business), zaś kooperujące firmy partnerskie przejmują pozostałe obowiązki. Dotyczą one działalności pomocniczej, zarówno zintegrowanej w formie Facility Management, jak i pozostałej, która będzie zlecana podmiotom wyspecjalizowanym (w ramach funkcji pomocniczych związanych z korzyściami skali lub ograniczeniami licencyjnymi w zakresie działalności).

Stawomir Kadziela

doktorant UJ, asystent w Katedrze Organizacji i Zarządzania Wydziału Zarządzania i Komunikacji Społecznej Uniwersytetu Jagiellońskiego w Krakowie

BIBLIOGRAFIA

[1] BIFM, Facilities Introduction, http://www.bifm.org.uk/index.mhtml?get = face/facilitiesintro.html

[2] CHAMIER-CIEMIŃSKI M., FM obniża koszt utrzymania,

„Outsourcing”, dodatek do „Pulsu Biznesu” 31.03.2005, s. 9.

[3] CZERMINSSKI A., GRZYBOWSKI M., FICOŃ K., Podstawy organizacji i zarzadzania, Wyższa Szkoła Administracji i Biznesu w Gdyni, Gdynia 1999.

[4] EuroFM, About EuroFM, http://www.eurofm.org/site/?c= $\mathrm{ww} \& \mathrm{l}=\mathrm{en} \& \mathrm{v}=1.0 \& \mathrm{a}=\mathrm{abou} \& \mathrm{p}=\mathrm{about} \cdot \mathrm{html}$

[5] Euroliance, A Profile of Euroliance EEIG, http://www.euroliance.com/euroliance_com.pdf

[6] IFMA, Definitions, http://www.ifma.org/whatsfm/definition.cfm?actionbig $=9$ \&actionlil $=168$

[7] IFMA, Facility Management Practices, http://www.ifma.org/ research/research/report16.cfm?actionbig $=24 \&$ actionlil $=284$

[8] M+W Zander, Facility Management, http://www.mw-zander.com/en/leistungen/leistungen fm 1 1.htm

[9] M+W Zander, References and Expertise, http://www.mwzander.com/en/referenzen/referenzen_fm.htm

[10] Marktübersicht der FM-Komplettdienstleister, „Der Facility Manager - Sonderausgabe" 2004.

[11] MARTYNIAK Z., Nowe metody i koncepcje zarzadzania, Wydawnictwo Akademii Ekonomicznej w Krakowie, Kraków 2002.

[12] PRODGERS L., FM wychodzi z pudetka, wywiad M. Szczecińskiej-Konstantynowicz, „The Manager. Facility and Property" $2004, \mathrm{nr} 4$.

[13] SABAT J., Lean Enterprise - czyli jak przedsiebiorstwa moga obniżyć koszty dziatalności, aby przetrwać na konkurencyjnych rynkach, http://www.it.info.pl/artykuly/artykul_ 4302.htm

[14] TROCKI M., Outsourcing. Metoda restrukturyzacji dziatalności gospodarczej, PWE, Warszawa 2001.

[15] ZIMNIEWICZ K., Wspótczesne koncepcje i metody zarzadzania, PWE, Warszawa 2000. 